the marine fauna of the silurian and other epochs ; and while now they occur only in the very deepest water, they were formerly found crowded in the shallower seas. The inquiry, th refore, suggested itself to the Professor as to the reason of this difference, and he makes the suggestion that in the progress of the earth's growth we may look to such displacement of conditions favourable to maintaining certain low types as may recall most fully the adaptation to former ages, and that the deeper waters of the present constitution of our globe possibly approximate the conditions of animal life in the shallow seas of former ages as nearly as anything can in the present order of things on the earth. The depth of the ocean alone, he thinks, can place animals under the high pressure which the heavier atmosphere of the earlier period afforded. But as such pressure cannot be a favourable condition for the development of life, it is to be expected that the lower forms only will occur in the deep seas. Other causes acting in the same direction are the decrease of light in the greater depths, the smaller amount of free oxygen, the reduced amount and smaller variety of nutritive substances, \&c. He does not think, however, that facts warrant the conclusion that any of the animals now living are lineal descendants of those of the earlier ages, nor that we may justly assume that the cretaceons formation is still extant, notwithstanding the similarity of forms. It would be just as true to nature to say that the tertiary period is exhibited in the tropics, on account of the similarity of the Miocene mammalia and those of the torrid zone. - The ninth number of the illustrated work on the butterfies of North America, in course of publication by Mr. William H. Edwards, has just made its appearance, and we are informed that the tenth number, to appear very shortly, will conclude the first volume. This number, like its predecessors, is accompanied by a great many quarto plates in the highest style of pictorial excellence, depicting some extremely beautiful species and varieties of butterflies. Among these are three varieties of Papilio Ajax, namely, Walshii, telamonides, and Marcellus. Mr. Edwards, in his paper, makes some judicious remarks upon the uncertainty that exists in regard to the true character of many butterflies which some naturalists consider as perfectly distinct species, and others as mere varieties. He takes the ground that the only way of coming to a satisfactory conclusion is to breed them, and ascertain whether the eggs from the same female develop similar larvæ or not, and whether these, even if different, produce the same perfect insects or different ones. The attempt at discriminating from the perfect insect alone he considers extremely unsatisfactory.

\section{ANNUAL ADDRESS TO THE GEOLOGICAL SOCIETY OF LONDON, FEB. 16, 1872}

By J. Prestwich, F.R.S., President

\section{(Concluded from $p .472$. )}

$\mathrm{T}^{\mathrm{T}}$ has been urged as a fatal objection to the discovery of coal in the south-east of England, that the Coal Measures become unproductive and thin out under the Chalk, as they range from Valenciennes towards Calais, and, therefore, that the coaltrough or basins end there. It is perfectly true that the Coal Measures do thin out between Bethune and Calais, but not in the sense of their dying out owing to their deposition near the edge of a basin. In that case, each seam, each stratum, would gradually become thinner and disappear; but such is not the fact. None of the beds of the Belgian coal-field are thick. The average docs not exceed $2 \frac{1}{4}$ feet. At Valenciennes it is the same; whereas M. Burat states the mean thickness of the beds actually increases westward of Bethume to more than $2 \frac{1}{2}$ feet. With respect also to the extreme end of this basin, the lower beds there brought up correspond with the bottom beds of the Hainault basin, where the lower 650 feet consist of unproductive measures. The thinning-out is, in fact, due to denudation, just as the Bristol coal-field thins out at Cromhall to resume in the Forest of Dean, or the coal-field of Liége thins out at Nameche to resume at Namur in the great field of Charleroi and Mons.

The deterioration of the coal in the small coal-field of Hardinghen, near Boulogne, has also been adduced against the occurrence of workable coal in South-Eastern England, but Mr. GodwinAusten has shown that this Hardinghen coal-field is one of those small local developments of coal-bearing strata intercalated in the Mountain Limestone, and is of older date than the great
Belgian coal-field. It has, therefore, no bearing on this part of the question.

Another objection to which much weight has been attached is that the coal-field of Bath and Bristol forms an independent basin, cut off both on the east and on the west by ridges of Millstone Grit and Mountain Limestone, so that there is an end of the eastern exlension of the Coal Measures. This is quite correct as far as regards the western edge, and is probably the case on the eastern, although as the edge of the basin is there covered by Secondary rocks, some uncertainty still exists about the disposition of the Palreozoic rocics under them. Admitting, however, the basin to be complete and isolated, that is no proof that the older Palæozoic rocks prevail exclusively to the east. for the Coal Measures of the Somerset basin maintain their full development to the edge of the basin, and are there cut off by denudation, and are not brought to an end by thinning out. They form really part of a more extended mass, of which we have there one fragment; while on the west another portion exists in the Welsh basin, and another in the newly discovered small basin of the Severn valley.

This last basin is entirely covered by the New Red Sandstone; and as the Welsh basin is bounded on the east and the Bristol basin on the west by Mountain Limestone, the same argument as the one above might have been used to show the impossibility of coal occurring in this intermediate area.

But the fact is, it is the very nature of this great line of disturbance to have minor rolls and flexures of the strata at, or nearly at, right angles to it, and so causing breaks in the coal. trough, which would otherwise flank it without interruption; thus the Aix-la-Chapelle coal-field is separated by older rocks from that of Liége, which is again separated by a ridge of Mountain Limestone from that of Hainaut. So in the case of south. western England, we have the several basins of South Wales, Severn Valley, and Bristol, separated by tracts of Mountain Limestone and Old Red Sandstone, the extremes of the inter. vening beits of older rocks being two miles at Nameche and eighteen miles in Wales. These barriers are clearly only local, and the division of the Coal Measures into separate basins appears to be their ordinary condition along this great line of disturbance. The length of the two known portions of the axis included between Pembrokeshire and Frome, and between Calais and Westphalia, is 472 miles, and in this distance we find eight separate and distinct coal-fields. The combined length of these eight coal-fields is about 350 miles, leaving about 122 miles occupied by intervening tracts of older rocks; so that vearly three-quarters of the whole length is occupied by coa!strata. I consider that a structure which is constant (so far as the axis of disturbance can be traced above ground) is, in all probability, continued under ground in connection with the range of the same line of disturbance; and I see no reason why the coal-strata should not occupy as great a proportionate length and breadth in the under-ground and unknown, as in the aboveground and explored area.

With respect to the possibility of denudation having removed the intervening Coal Measures, enormous as the extent of denudation must have been previous to the deposition of the Permian strata, we cannot admit its exceptional action in this case. Denudation has removed from the crest of the Mendips a mass of strata possibly equal to two miles or more in height, and from that of the Ardennes as much as three or four miles, and it has also worn extensive channels between many of our coalfields, so that the power of such an agent cannot be denied. But it is a power of planing down exposed surfaces rather than of excavating very deep troughs. Notwithstanding its immense planing-down action on the Mendips and Ardennes, deep troughs of Coal Measures are left flanking their northern slopes. These troughs descend to more than a mile beneath the level of the sea; and $I$ do not think it probable that those underground intermediate portions of the trough where the axis is lower, would have suffered more than those on the higher levels, unless it were to the extent caused by the later denudation which preceded the Cretaceous period. But this would not affect the main bulk of the Coal Measures. The Belgian coal-field, which was exposed to the action of both these denudations, still retains vast proportions.

I may remark that the pre-Cretaceous denudation was very irregular in its action. At one place near Mons the Chalk and Tertiary strata are above 900 feet thick; whilst at another, on about the same level, and at but a short distance, they are not too feet thick-an old under-ground; hill of highly inclined 
Coal Measures causing this difference, and rising in the midst of the unconformable newer strata. This shows that in the English Chalk area we may possibly find irregular old surfaces of this kind, so that the Coal Measures may exist at places nearer the surface than we have estimated.

We have alluded before to the great length and narrow width of the Belgian conl-fields. That of Liege is forty-five miles long, with a mean width of less than four miles, whilst that of I Iainaut and Valenciennes is IIg miles long, with a width scarcely greater. The presence of lower Carlsoniferous rocks under Harwich, and the wider range north and south of the Bristol coal-field, renders it possible that the trough in the intermediate area may have a greater expansion than in Belgium; but we have nothing else to guide us, unless it be that the lateral pressure in the intermediate ground was probably less than in the Ardennes and the Mendips, where it has exercised its maximurn elevatory force. In that case the cual-trough in this intermediate area would be less compressed and more expanded; so we might consequently here look to find larger coal-basins than either tiose of Somerset or Liége. The position of these basins I am disposed, for reasons given in my Report, to place farther north than $\mathrm{Mr}$. Godwin-Austen, and should therefore look for them not in the valley of the Thames, or on the line of the North Downs, but under South Essex, Middlesex or Hertfordshire, Oxfordshire, and North Wiltshire.

The strata on the south side of the Liége coal-field rise abruptly against highly inclined and faulted Devonian rocks, and the north side they rise at a less angle beneath Cretaceous or Tertiary strata. In the frainaut coal-field the overlying have a greater extension. Under these strata the Coal Measures are succeerled by the Mountain Limestone, and then by Devonian or Silurian strata; but with one or two limited exceptions their outcrop is hidden by the newer strata which stretch uninterruptedly northward over the rest of Belgium. The Paleozoic strata have; however, been met with near. Brussels, under Tertiary strata, at a depth of about 600 feet, and at Ostend at a depth of 985 feet, of which 682 consisted of lower Tertiary strata, 2ro feet of Chalk, and 93 of coloured marls. It appears, therefore, not improbable, that the Tertiary and Cretaceous strata of all Belgium may repose directly on a floor of Palæozoic rocks; and as there is reason to suppose that all these rocks have a strike parallel with that of the Ardennes, folds in the strata may bring in some under-ground coal-basin or basins in parallel lines to the north, in the same way that small troughs of Coal Measures are brought in again in the Ardennes to the south of the great coal-trough. On the other hand, the great Palæozoic axis of the Ardennes, consisting of Silurian and Devonian rocks, Mountain Limestone, and Coal Measures, passes westward under the Chalk of the north of France, and has been followed under ground as far as to Calais, where it lies at a depth of 1,032 feet ; while in the direction of Boulogne it keeps nearer the surface, outcrops from beneath the Chalk downs surrounding the Boulonnais, and disappears westward under an unconformable series of Jurassic and Wealden strata.

We may, I think, look for a prolongation of this old Palæozoic surface of highly inclined, contorted, and faulted rocks at no very great depth under the same Wealden, Chalk, and Tertiary area of the south of England. For, although the old Palæozoic surface descends rapidly from about 300 feet above the sea-level in the Boulonnais to rozo feet below it at Calais, it rises at Ostend 47 higher than at Calais, and crossing the Channel, it is found at Harwich within a few feet of the same depth as at Calais, from which it is eighty miles distant in a northerly direction. Passing westward from Calais, we find the Palrozoic rocks under London 105 miles distant, and 102 feet higher than under Calais, and 106 feet higher than at Harwich. Allowing for irregularities of the old surface as evinced by the well at Crossness, near Plumstead, which was still in the Gault at a depth of 944 feet, or some 14 feet below the level of the Palæozoic rocks at Kentish Town, we may still consider that in the area between these three points, and pos. sibly throughout the south-east of England, the Palrozoic rocks will probably be found not to be more than from I,000 to 1,200 feet beneath the sea-level.

Projecting the line another 100 miles westward, we reach the neighbourhood of Bath and Frome, where the Coal Measures are, as before mentioned, lost at a depth of about $45^{\circ}$ feet, beneath Liassic and Jurassic strata. In the intermediate area between that place and London no trial-pits and no wells have been carried to a depth of anything like $x, 000$ feet beneath the sea-level. The deepest well with which $I$ am acquainted is one near Ch ibham, in Surrey, through Tertiary strata and Chalk to a depth of about 800 feet, or of 550 feet beneath the sea-level

There are, however, in all this area certain indications of the proximity of old land and of pre-Cretaceous denudation, in the presence of quartz and Lydian pebble-stones, accompanied by Secondary ro.k fossils in the Lower Greensands of Surrey, and in the like old rock pebhles, with the addition of slate pebbles, in that form ition in North Wiltshire; while the banks of shingle, Bryozoa, and sponges of the same age at Farringdon, point to sill and sheltered waters, probably of no great depth, and to a fijacent dry land. Again, on the north of London, we have in the Lower Greensand of Buckinghamshire and Bedfordshire shingle beds consisting almost entirely of fossils derived from Jurasic striata, with a remarkable collection of larger quartz, quartzite, and ofher rock-pebbles, derived probably from the old Palarizinic axis.

On the south alio of the great Mendip and Ardennes axis coal strata may possibly be found just as they are fuund on buth sides of the Pennine chain; for in either case the measures are cut off and broken through by these chains of hills. In South Wales certain folds of the older strata seem to render it probable that the Coal Measures may pass under the Bristol Channel, forming a trough which prolonged eastward would pass along the south side of the Mendips. Trials in the latter area, have, however, shown that the New Red Sandstone, Lias, and Oolitic series attain an infinitely greater thickness than on the north flank of that range, so that it is not likely that the Coal Measures would lie at a less depth than from 1,500 to 2,000 feet.

On further consideration of the subject, it seems to me a question whether we should not take a still broader view of this great east and west axis, ard assign to it a width varying from thirty to eighty miles or more, looking at the Mendips and Exmoor hills as the bounding flexures north and south of the same line of disturbance in South-western England, while the ridges of the Ardennes, the Eifel, and the Hundsruck (in part?) are exhibitions of the same parallel series of anticlinals. In that case the great coal-basins of South Wales and Somerset would represent the synclinal trough on one side of the axis of disturbance, and on the other side we should have the Lower Calr. boniferous or Coal Measures of Devon ; while on the Continent the deep, narrow synclinal trough of the Liége and Aix-laChapelle basin may be considered as lying on one side of the arch, and the great coal-basin of Saarbruck on the other. This important coal-basin has already been followed under the New Red Sandstones of the Vosges for a distance of from twenty-four to thirty miles in the direction of Metz, still on the strike of the Ardennes. Further westward, a trial for coal near Doncherry led to the discovery of Palrozoic rocks, at a depth of 1,090 feet under that thickness of Lias and Infralias; but the line of the coal-trough should, I think, pass a few miles to the south of this spot. Thence this underground coal-trough would range in an irregular east and west line, keeping parallel, or nearly parallel, with the Mons and Valenciennes troughs, under the north of Champagne, Normandy, the Channel, between the Isle of Wight and Cherbourg, Dorset, and cropping out again in North Devon. The only deep sections that $I$ know of on this line are those furnished by a well sunk many years since, nine miles east of Dieppe, to a depth of 1,092 feet in the Kimmeridge clay and other strata; and another by a boring at Sotteville, near Rouen, through a thin capping of Cretaceous strata, to a depth of $\mathrm{r}, 05 \mathrm{O}$ feet in the same Kimmeridge clay--in either case without reach. ing the Palæozoic rocks. At Paris no Palæozoic rocks have been reached at a depth of 2,000 feet.

In this country the newer strata, overlying the Palæozoic rocks on our presumed anticlinal line, have been sunk through, without result, in the lowest beds of the Wealden at Hastings to a depth of 486 feet, in the upper beds at Earlswood, near Reigate, to a depth of about 900 feet, and, on the presumed synclinal line of Carboniferous rocks, through Chalk at Chichester, to a depth of 945 fcet, and at Southampton, through Tertiary strata and Chalk to a depth of 1,317 feet.

To the south of all the area we have now described, there existed during the Carboniferous period, the ranges of the older Palrozoic strata of the Hunsdruck and Vosges-ot the old crystal. line rocks of Central France, fringed on the east and north with small outlying coal basins of the old Palæozoic rocks of Brittanyand of the Silurian rocks of South Cornwall-forming the old land-surface, fringed by the great coal-growths subtended northwards through Northern France, Western Prussia, Belgium, and 
England, to the Silurian uplands of Central Scotland on the north, and those of the Welsh and Cumbrian highlands on the west, and possibly to those of the Scandinavian hills on the north-east. After the formation and consolidation of the Coalstrata, the southern area of this great Carboniferous basin was then subjected to that remarkable disturbance which, for a distance of above 800 miles, exercised that excessive lateral pressure by which the older underlying strata were squeezed and forced up into the series of sharp anticlinals forming the axis of the Mendips and Ardennes, while portions only of the Carboniferous series were preserved from the denudation which followed, in deep synclinal troughs flanking the main axis.

The central and northern portions of the great Carboniferous basin, which were not raised by this disturbance, were then overspread by strata of the Permian series; after which the northern section of the original coal area was traversed by that other great disturbance at nearly right angles to the former one, by which fresh portions of the Coal Measures were brought up in our central and northern counties, still leaving other deeper-seated portions to be afterwards covered by Triassic and Jurassic strata.

At a much later period the emerged southern area of Palæozoic rocks, including the westward prolongation of the great coaltrough of Belgium, or portions thereof, was submerged and covered over by the several formations of the Greensands, Chalk, and Lower Tertiaries now forming the surface of the south east of England.

The trials to discover these possibly productive coal-basins must necessarily be attended with considerable uncertainty. We shall have to feel our way. Of our hope of their ultimate success I have given you the reasons. Nor could such trials near London scarcely fail of some important results ; for, even if we did not hit at first upon the Coal Measures, it is probable that the Lower Greensand would at some spots be reached, so that the inestimable additional benefit of a large and steady supply of pure water might also be obtained, and, with proper care to prevent undue interference, might be maintained for all time.

And now, gentlemen, in retiring from the chair, which I have had the honour to occupy during the last two years, allow me to express the sincere satisfaction I have experienced in witnessing the continued prosperity of the Society, and the unanimity and oneness with which its labours are carried on. It was a post I long hesitated to accept, but which your kind forbearance and the friendly co-cperation of your officers, has not only rendered easy, but as pleasant as it has been gratifying. I feel assured of the continurd prosperity and usefulness of the Society when I resign my trust into the hands of a nobleman, so distinguished as a statesman, so able as a writer, and so long known amongst us an active and zealous geologist, as the Duke of Argyll.

\section{SCIENTIFIC SERIALS}

The Lens, a quarterly journal of microscopy and the allied natural sciences, with the Transactions of the State Microscopical Society of Illinois, edited by S. A. Brigg. No. I, January 1872. Chicagro, U.S. This long-promised journal has at length made its appearance, and we learn from its first number that it was printed and ready for the mail when the great fire occurred. With the exception of a few copies, the whole edirion was destroyed, and un recovery from that disaster had to be reprinted. We have cause, therefore, to congratulate the publishing committee on recovering themselves so speedily as to issue their first number with the new year. Amongst its contents we note the following:- "Conspectus of the families and genera of the Dratomacere," by Prof. H. L. Smith. This is an artificial key, and like all such effurts has its good and bad sides. As a help such guides are useful, but they are seldom satisfactory. A table of synunyms is promined in the next number. "The Flora of Chicago and its vicinity," by H. II. Babcuck, is hardly such a subject as we should expect to find in a microscopical journal, siuce the list of Phanerogamic plants, with localities, here commenced, contains no single note of microscopical observation. To the local botanist it will probably make amends for this by its practical utility.- "On the preparation and preservation of sections of soft tissues," by Dr. I. N. Danforth, contains practical ohservations on the preparation of morhid animal tissues without artificial hardening.- - "Microscopical Memoranda for the use of Pracitioners of Medicme," by Dr. J. J. Woodward, U.S. Army, is the first purtion of a mure elaborare treatment of the same subject, which is to be contained in succeeding num- bers. Dr. Woodward's reputation on this side the Atlantic as a practical microscopist is a sufficient guarantee for these memoranda. - "A new fossil Echinus," by O. S. Wescott, is named by the author Oligoporus Groveri, and found in the limestone region of Hancock County, Illinois. - "The Diatomaceæ of Lake Michigan," by S. A. Briggs, is simply a list of species. - "A New Method of Illuminating Opaque Objects under high powers," by Dr. H. A. Johnson. This new method consists in sending a beam of light down the oblique body of the bi. nocular upon the prism, by means of a plane mirror or rectangular prism; by this arrangement objectives as high as $\frac{1}{25}$ in. have been used successfully by daylight and lamplight. - A reprint from the Monthly Microscopical Fournal and some notes complete the present number. The Iosses which the Academy of Sciences of Chicago sustained by the late destructive fire are detailed, in so far as the natural history collections and library are concerned. All British naturalists will sympathise with those of Chicago at their irreparable misfortune in such losses as the Smithsonian collection of crustacea, which filled I0,000 jars, and the invertebrates of the U.S. North Pacific Exploring Expedition, besides the thousands of specimens, zoological, botanical, and mineralogical, in the general collection.

Fournal of the Chemical Society, Jan. 7, I872, - Dr. Gladstone has continued his experiments on various essential oils; amongst others he has examined four new oils, those of citron, lign aloes, pimento, and vitivert; the author has separated the hydrocarbons contained in most essential oils into three polymeric groups to which the formulæ $\mathrm{C}_{10} \mathrm{H}_{16}, \mathrm{C}_{15} \mathrm{H}_{24}$, and $\mathrm{C}_{20} \mathrm{H}_{32}$, have been as signed. The two bodies first mentioned have the vapour density required by theory, the third has not been examined, the three bodies also differ in their solubility in alcohol, and in their expansibility by heat. The physical properties and chemical compo. sition of several oils have been studied in detail, and are here described. Dr. Armstrong contributes a third paper on the nitrochlorphenols, the results obtained, however, are not suitable for useful abstraction. Amongst the abstracts there is one by E. Budde "on the action of light on Chlorine and Bromine." The author has exposed chlorine to the action of various parts of the solar spectrum, he found that when the bulb of gas was exposed to the violet and ultra-violet rays, there was from six to seven times as great expansion as took place in the red and yellow part of the spectrum. An ordinary differential air thermometer and also one charged with carbonic anhydride and ether, placed in the blue and violet parts of the spectrum, showed no increase in temperature. The author is of opinion that the hypothesis which he has advanced in explanation "that the chemically active light actually decomposes the chlorine molecules into chlorine atoms" is not a little supported by the fact that the rays which cause the expansion of chlorine coincide with those which are known to render it chemically active. The author believes that the light causes the separation of the molecules into atoms, and that the isolated atoms combine again with the production of heat, and thus lead to an increase of temperature which would account for the expansion of the gas as observed.

THE articles of most general interest in the fournal of the Franklin Institute for January are by Mr. F. A. Genth, on the Mineral Resources of North Carolina; and by Mr. G. W. Baird, U.S.N., on the Absorption of Gases by Water, and on the organic matters contained therein. The latter contains a series of experiments on the volume of different gases capable of being dissolved in a unit volume of water, and on the amount of oxygen necessary to oxidise the organic matter contained in the water.-The editorial notes contain descriptions of a number of novelties in mechanics and physics. - Mr. J. Farrand Henry continues his series of papers on the Flow of Water in Rivers and Canals, and Mr. J. H. Cooper his article on Belting Facts and Figure:- - There is also a report by Mr. W. M. Henderson on some experiments on the explosion of steam-boilers, carried out by a committee of the Franklin Institute at the instance of the engineers of some of the American railways.

The American Foumal of Science and Art for February is mainly geological. It commences, however, with some observations by Prof. C. A. Young on Encke's comet, at the Dartmouth College Observatury, accompanied by drawings. He identifies the spectrum with that of Comet II. I868 (Winnecke's comet) described by Mr. Huggins in the Philosophic Transactions for that year.Prof. J. D. Whitney has a note on the occurrence of the "Primordial Fauna" of Nevada, which he considers indicates most unequivocally the Potsdam period of the Silurian age, and carries 